\title{
Penentuan Lokasi Titik Evakuasi Sementara Bencana Tsunami Menggunakan Metode Network Analyst (Studi Kasus: Pesisir Selatan Kabupaten Pangandaran) Locations Determination of Temporary Evacuation Point for Tsunami Disasters using The Network Analyst Method (Case Study: South Coast of Pangandaran Regency)
}

\section{Nurwatik*, Filsa Bioresita, Darma Setiawan}

Departemen Teknik Geomatika, FTSLK-ITS, Kampus ITS Sukolilo, Surabaya, 60111, Indonesia

*Korespondensi penulis: nurwatik@its.ac.id

Diterima: 14082021; Diperbaiki: 19092021; Disetujui: 25102021; Dipublikasi: 10012022

\begin{abstract}
Abstrak: Bencana Tsunami merupakan salah satu bencana alam yang sangat berbahaya dan sering terjadi di Indonesia. Khususnya pada daerah Pesisir Selatan Kabupaten Pangandaran yang memiliki riwayat tsunami dengan ketinggian run up tsunami mencapai 15,7 meter pada tahun 2006 berdasarkan data BPBD Kabupaten Pangandaran. Menurut BMKG tsunami yang terjadi tersebut menelan korban jiwa sebanyak 664 orang. Sebagai upaya mitigasi bencana pada penelitian ini dilakukan analisa tingkat bahaya tsunami dan penentuan lokasi Tempat Evakuasi Sementara (TES) pada Wilayah Pesisir Selatan Kabupaten Pangandaran. Analisa tingkat bahaya dilakukan berdasarkan data kelerengan, koefisien kekasaran, ketinggian run up tsunami, dan garis pantai. Kemudian dari hasil analisa tingkat bahaya tersebut digunakan untuk menentukan lokasi TES menggunakan metode Network Analyst. Dasar pembuatan sebaran lokasi TES yaitu dengan menggunakan analisa Service Area berdasarkan lokasi sebaran TES yang telah ada sebelumnya dari BPBD Kabupaten Pangandaran. Dari analisa tersebut akan diidentifikasi sebaran lokasi TES dan cakupan area. Apabila cakupan Service Area sebaran lokasi TES dari BPBD Kabupaten Pangandaran belum mencakup keseluruhan wilayah terdampak tsunami, maka dilakukan penambahan titik lokasi TES. Penelitian ini menghasilkan 55 titik lokasi TES yang dapat digunakan sebagai tempat evakuasi dengan waktu tempuh maksimal 22 menit.
\end{abstract}

Copyright () 2022 Geoid. All rights reserved.

\begin{abstract}
A tsunami disaster is one of the most dangerous natural disasters and often occurs in Indonesia. Especially in the South Coastal area of Pangandaran Regency which has a history of tsunamis with a tsunami run-up height reaching 15.7 meters in 2006 based on data from BPBD Pangandaran Regency. According to the BMKG, the tsunami that occurred killed 664 people. As a disaster mitigation effort, this research analyzed the level of tsunami hazard and determined the location of Temporary Evacuation Places (TES) in the South Coastal Region of the Pangandaran Regency. The hazard level analysis was carried out based on slope data, roughness coefficient, tsunami run-up height, and coastline. Then from the results of the analysis of the hazard level are used to determine the location of TES using the Network Analyst method. The basis for making the distribution of TES locations is by using Service Area analysis based on pre-existing TES distribution locations from BPBD Pangandaran Regency. From this analysis, the distribution of TES locations and coverage areas will be identified. If the Service Area coverage of the distribution of TES locations from BPBD Pangandaran Regency does not cover the entire tsunami-affected area, then additional TES points will be made. This study resulted in 55 TES location points that can be used as evacuation sites with a maximum travel time of 22 minutes.
\end{abstract}

Kata kunci: Kabupaten Pangandaran; Network Analyst; TES; Tsunami

Cara untuk sitasi: Nurwatik, Bioresita, F., \& Setiawan, D. (2021). Penentuan Lokasi Titik Evakuasi Sementara Bencana Tsunami Menggunakan Metode Network Analyst (Studi Kasus: Pesisir Selatan Kabupaten Pangandaran). Geoid, 17(1), 53-61.

\section{Pendahuluan}

Wilayah Pulau Jawa khususnya di daerah pantai selatan Kabupaten Pangandaran, Jawa Barat. Memiliki riwayat bencana tsunami pada tahun 2006 dengan magnitude gempa 7,7 SR. Sehingga menimbulkan gelombang tsunami setinggi 3-8 meter yang menelan 664 korban jiwa (BMKG, 2019). Tsunami tersebut 
menimbulkan run up tsunami mencapai 8meter hingga 15,7 meter yang bersumber dari data BPBD Kabupaten Pangandaran. Akibat dari bencana tsunami tersebut membuat fasilitas umum, rumah, dan bangunan lainnya mengalami kerusakan. Tingkat kerusakan bangunan secara umum berkaitan dengan tinggi gelombang tsunami yang menerjang serta jenis konstruksi bangunannya. Tingkat kerusakan bangunan bervariasi dari kerusakan total atau mendekati total untuk rumah dengan konstruksi batu bata lama. Dengan penguatan bangunan menggunakan beberapa kolom beton tingkat kerusakannya sekitar 50\% sedangkan untuk bangunan baru dan diperkuat dengan konstruksi beton yang besar maka tingkat kerusakannya lebih kecil yaitu sekitar 5 sampai 20\% (Tejakusuma, 2008).

Dalam upaya penanggulangan bencana terdapat tahap pra bencana, yang merupakan kegiatan untuk modal menghadapi bencana. Tahap pra bencana terdapat kegiatan pencegahan, mitigasi, peringatan dini, dan kesiapsiagaan. Peningkatan kesiapsiagaan masyarakat terhadap bencana merupakan hal yang penting untuk diperhatikan. Hal ini disebabkan sebagian besar korban akibat bencana mengalami kondisi panik mengungsi sehingga menimbulkan kekacauan (Permana \& Rasyid, 2007). Salah satu bentuk kesiapsiagaan yaitu adanya penentuan lokasi TES yang bertujuan untuk meminimalisir korban jiwa. Dalam penentuan TES dapat menggunakan metode Network Analyst. Network Analyst digunakan untuk menentukan jalur tercepat atau terpendek antar lokasi yang diteliti (Rai et al., 2013). Penentuan rute terbaik oleh metode Network Analyst dilakukan dengan menggunakan sebuah algoritma yang dikembangkan oleh Edgar Dijkstra (1959). Algoritma Dijkstra digunakan untuk mengkalkulasi jalur terpendek dari titik awal ke semua titik lainnya. Sehingga sangat optimal dalam melakukan evakuasi bencana ke tempat yang aman.

Menggunakan metode Network Analyst akan menghasilkan lokasi TES yang telah dilakukan analisa jaringan. Dengan menggunakan data-data jaringan jalan dan lokasi TES yang selanjutnya disingkat dengan TES dari BPBD Kabupaten Pangandaran pada wilayah pesisir selatan Kabupaten Pangandaran. Data jaringan jalan yang diperoleh dari Open Street Map (OSM) digunakan karena data vektor dari OSM memiliki waktu pembaharuan yang relatif up to date yaitu diperbarui setiap waktu (N. K. Dewi \& Purwanto, 2017). Data OSM lebih fleksibel dan dapat segera diperbarui saat ada perubahan di lapangan sedangkan peta milik pemerintah biasanya diperbarui dalam jangka waktu tertentu (Yashinta et al., 2019).

Pada penelitian ini akan dilakukan analisis daerah terdampak tsunami, penentuan jalur serta sebaran lokasi TES yang efektif untuk tempat evakuasi menggunakan metode Network Analyst. Dalam analisis daerah terdampak tsunami menggunakan metode yang telah ditetapkan oleh BNPB berdasarkan parameter-parameter tertentu. Karena pada saat terjadi bencana Tsunami diharapkan masyarakat dapat menuju lokasi TES dengan cepat untuk mengurangi korban jiwa. Sasaran khusus dalam penelitian ini jalur diperuntukkan dalam evakuasi manusia.

\section{Data dan Metode}

Pada penelitian ini menggunakan data spasial Peta RBI 1:25.000 dari Badan Informasi Geospasial, data jaringan jalan dari Open Street Map, DEMNAS dari Badan Informasi Geospasial, peta jalur dan TES bencana tsunami tahun 2017 dari BPBD Kabupaten Pangandaran, dan data ketinggian run-up tsunami Kabupaten Pangandaran tahun 2006 dari BMKG. Kemudian perangkat lunak yang digunakan pada penelitian ini seperti ArcGIS 10.5, ENVI 5.3, SNAP, Microsoft Word 2019, Microsoft Excel 2019.

Pengolahan data dilakukan dengan beberapa tahapan yang dijelaskan pada poin-point dibawah ini:

1. Koreksi Atmosfer

Data Citra Sentinel 2A Level 1C yang didapatkan maka dilakukan koreksi atmosfer dengan tujuan untuk mendapatkan nilai BOA (Bottom of Atmosphere) reflectance sehingga data yang digunakan merepresentasikan permukaan bumi tanpa pengaruh atmosfer. Sehingga mendapatkan data Citra Sentinel dengan level 2A yang terbebas dari pengaruh atmosfer. 


\section{Klasifikasi Citra}

Klasifikasi dilakukan pada citra yang telah disubset. Kemudian dalam proses klasifikasi dilakukan dengan data dari Peta RBI 1:25.000 untuk proses klasifikasi terbimbing (supervised) menggunakan metode Maximum Likelihood Classification (MLC) pada citra satelit Sentinel 2A. Dengan jumlah kelas klasifikasi berdasarkan jenis tutupan lahan pada peta RBI. Sehingga menghasilkan data tutupan lahan sesuai dengan kelas pada peta RBI.

\section{Uji Klasifikasi}

Hasil klasifikasi citra dilakukan uji klasifikasi untuk mengetahui tingkat ketelitian klasifikasi yang dilakukan. Uji klasifikasi berhasil jika memenuhi nilai overall accuracy > 85\% dari hasil confusion matrix (Lillesand \& Kiefer, 1997). Dengan uji klasifikasi pada tutupan lahan menggunakan data peta RBI untuk mengetahui nilai overall accuracy. Jika hasil uji klasifikasi belum memenuhi maka dilakukan klasifikasi kembali.

\section{Raster Koefisien Kekasaran}

Raster koefisien kekasaran dihasilkan dari klasifikasi citra yang di reclassify menjadi 9 kelas yaitu: badan air, hutan, pemukiman, lahan kosong, sawah, kebun, semak, mangrove, dan tambak. Kemudian data tersebut digunakan untuk menghitung nilai Hloss (BNPB, 2016). Dengan nilai koefisien kekasaran ditunjukkan pada Tabel 1.

Tabel 1. Indeks Koefisien Kekasaran (Berryman 2006)

\begin{tabular}{ccc}
\hline No & Tutupan Lahan & Nilai Koefisien \\
\hline 1 & Badan air & 0,007 \\
\hline 2 & Belukar/Semak & 0,040 \\
\hline 3 & Hutan & 0,079 \\
\hline 4 & Kebun/Perkebunan & 0,035 \\
\hline 5 & Lahan kosong/Terbuka & 0,015 \\
\hline 6 & Lahan Pertanian & 0,025 \\
\hline 7 & Permukiman/Lahan terbangun & 0,045 \\
\hline 8 & Mangrove & 0,025 \\
\hline 9 & Tambak/Empang & 0,010 \\
\hline
\end{tabular}

5. Perhitungan Nilai Hloss

Perhitungan nilai Hloss yang dikembangkan oleh Berryman (Berryman, 2006) dilakukan dengan menggunakan data peta kelerengan dengan satuan radian. Kemudian mengunakan data raster koefisien kekasaran dan data ketinggian run-up tsunami 8 meter diambil dari studi kasus tsunami pangandaran 2006 sumber BMKG dan BPBD Kabupaten Pangandaran. Perhitungan Hloss dengan menggunakan rumus berikut:

Hloss $=\frac{167 n^{2}}{H o^{\frac{1}{3}}}+5 \sin S$

Keterangan:

Hloss = Kehilangan ketinggian tsunami per 1meter jarak genangan

$\mathrm{n}=$ Kehilangan ketinggian tsunami per 1meter jarak genangan

$\mathrm{Ho}=$ Ketinggian gelombang tsunami di garis pantai

$\mathrm{S} \quad=$ Besarnya lereng permukaan

6. Indeks Bahaya Tsunami

Hasil perhitungan nilai Hloss dilakukan analisis cost distance dengan memperhitungkan dari data garis pantai. Kemudian dilakukan estimasi area rendaman dan dilakukan klasifikasi tingkat bahaya tsunami berdasarkan Buku RBI (Resiko Bencana Indonesia) BNPB Tahun 2013. Hal ini dilakukan dengan tujuan mengetahui perbedaan bahaya yang dihasilkan dari tinggi gelombang tsunami yang pernah terjadi pada daerah tersebut.

\section{Pembuatan Network Dataset}


Network Dataset dibuat mengunakan input data jaringan jalan yang telah dilakukan proses Break line at vertice untuk memisahkan setiap vertice jalan yang akan diproses dalam network dataset. Sebelumnya pada data jaringan jalan telah dilakukan input data kecepatan tempuh evakuasi dan alokasi waktu pada setiap vertice jalan untuk mengetahui waktu tempuh dari setiap vertice jalan. Dengan kecepatan berjalan manusia $0,751 \mathrm{~m} / \mathrm{s}$ dan alokasi waktu evakuasi 22 menit (R. S. Dewi, 2012). Alokasi waktu tersebut ditentukan karena sasaran objek yang dievakuasi adalah masyarakat setempat yang terdampak tsunami. Kemudian dilakukan pengaturan data parameter pada proses pembuatan network dataset di antaranya yaitu, panjang jalan, atribut one-way, dan waktu tempuh pada setiap vertice jalan.

\section{Analisis Service Area}

Analisis service area bertujuan untuk mengetahui cakupan jalan yang dapat dicapai dengan menggunakan parameter waktu tempuh 22 menit. Parameter waktu 22 menit tersebut diambil dari penelitian sebelumnya (R. S. Dewi, 2012). Dengan menggunakan validasi waktu kedatangan tsunami (ETA) yang diperoleh dari BPBD Kabupaten Pangandaran yaitu selama 40 menit pada studi kasus tsunami Pangandaran tahun 2006. Waktu evakuasi (Evacuation Time/ET) atau waktu respon bagi masyarakat dapat dikalkulasi berdasarkan formula Post dkk. (2009) dalam (R. S. Dewi, 2012) berikut:

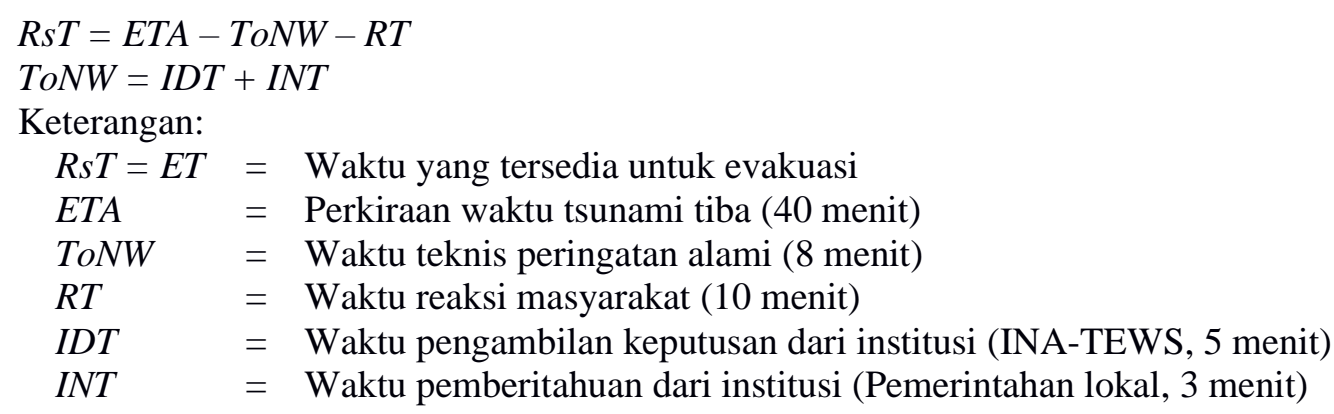

Kemudian dilakukan input data yang digunakan yaitu data TES yang sudah ada dari peta lokasi sebaran TES BPBD Kabupaten Pangandaran. Analisis service area menghasilkan polygon area sesuai dengan parameter waktu tempuh 22 menit.

\section{Pembuatan Titik Lokasi TES Tambahan}

Pembuatan titik lokasi TES tambahan dan lokasi titik awal insiden tsunami (start point) berdasarkan data analisis service area dengan mempertimbangkan area permukiman terdampak. Pada daerah yang tidak tercakup oleh service area data TES yang sudah ada dari peta lokasi sebaran TES BPBD Kabupaten Pangandaran. Kemudian dilakukan penambahan titik lokasi TES tambahan untuk memperoleh cakupan service area yang dapat menjangkau semua akses jalan di wilayah terdampak tsunami.

Penambahan titik lokasi TES ditentukan berdasarkan Indeks Bahaya Tsunami yang terjadi pada lokasi studi dan mempertimbangkan permukiman pada sekitar lokasi TES yang akan ditambahkan. Lokasi TES tambahan ditentukan pada daerah yang tidak terdampak tsunami atau pada daerah terdampak dengan indeks bahaya rendah. Untuk penentuan lokasi titik awal tsunami (start point) ditentukan pada lokasi yang paling dekat dengan garis pantai. Dengan tipe TES yang ditentukan yaitu TES berupa bukit alami atau sebuah rekomendasi lokasi TES tambahan untuk dibangun TES untuk evakuasi vertikal. Kemudian hasil TES tambahan dilakukan analisa service area kembali.

\section{Analisa Service Area TES Tambahan}

Analisa service area titik lokasi TES tambahan dilakukan untuk mengetahui jangkauan service area pada lokasi TES keseluruhan (termasuk titik lokasi TES data BPBD Kabupaten Pangandaran) menggunakan parameter waktu tempuh 22 menit. Jika pada analisa ini masih terdapat jalan yang terdampak tsunami tidak terjangkau oleh service area ini, maka dilakukan penambahan titik lokasi TES dan titik awal insiden tsunami kembali. Jika pada analisa ini seluruh wilayah studi yang terdampak tsunami sudah terjangkau oleh seluruh service area, 
kemudian dilakukan proses kesesuaian titik lokasi TES data dari BPBD Kabupaten Pangandaran dan titik lokasi TES tambahan.

\section{Hasil dan Pembahasan}

\section{Tutupan Lahan}

Pada penelitian ini dilakukan klasifikasi citra menjadi 9 kelas yang terdiri dari badan air, hutan, lahan pertanian, mangrove, perkebunan, pemukiman, semak belukar, tambak, dan lahan kosong. Pembagian kelas tersebut digunakan untuk membuat peta bahaya tsunami yang selanjutnya diolah menjadi koefisien kekasaran yang digunakan dalam rumus Beryman.

Metode klasifikasi yang digunakan adalah metode klasifikasi terbimbing (supervised) yaitu metode Maximum Likelihood Classification (MLC). Metode ini memiliki tingkat ketelitian yang tinggi (Lillesand \& Kiefer, 1997). Dengan proses klasifikasi terbimbing dilakukan dengan bantuan peta RBI yang bersumber dari Badan Informasi Geospasial. Dengan Tabel 2 menujukkan hasil klasifikasi tutupan lahan.

Tabel 2. Luas tutupan lahan Kabupaten Pangandaran

\begin{tabular}{ccccccc}
\hline Tutupan lahan & \multicolumn{7}{c}{ Luas (Hektare) } \\
\cline { 2 - 7 } & $\begin{array}{c}\text { Kecamatan } \\
\text { Cimerak }\end{array}$ & $\begin{array}{c}\text { Kecamatan } \\
\text { Cijulang }\end{array}$ & $\begin{array}{c}\text { Kecamatan } \\
\text { Parigi }\end{array}$ & $\begin{array}{c}\text { Kecamatan } \\
\text { Sidamulih }\end{array}$ & $\begin{array}{c}\text { Kecamatan } \\
\text { Pangandaran }\end{array}$ & $\begin{array}{c}\text { Kecamatan } \\
\text { Kalipucang }\end{array}$ \\
\hline Badan Air & 39.51 & 62.9 & 40.66 & 18.12 & 60.3 & 76.38 \\
\hline Hutan & 1604.94 & 1508.82 & 2004.05 & 1629.85 & 1138.93 & 1181.34 \\
\hline Lahan Pertanian & 5000.71 & 2392.91 & 2540.52 & 2187.93 & 2034.36 & 2742.58 \\
\hline Mangrove & 874.72 & 681.13 & 682.65 & 510.36 & 351.25 & 270.39 \\
\hline Permukiman & 1433.83 & 328.56 & 426.98 & 379.02 & 414.1 & 291.6 \\
\hline Perkebunan & 616.6 & 287.48 & 304.51 & 282.31 & 233.59 & 372.7 \\
\hline Semak Belukar & 7499.52 & 3633.19 & 4245.99 & 3092.07 & 2353.28 & 3518.64 \\
\hline Tambak & 56.71 & 56.04 & 79.59 & 113.77 & 81.94 & 79.4 \\
\hline Tanah Kosong & 1476.34 & 568.97 & 776 & 708.77 & 694.02 & 702.44 \\
\hline
\end{tabular}

Pada hasil klasifikasi dilakukan uji klasifikasi menggunakan menggunakan 30 titik uji pada setiap kelas. Dengan menggunakan hitungan matriks konfusi, uji klasifikasi menghasilkan nilai overall accuracy 88.1881\%. Hasil tersebut sudah memenuhi nilai minimal overall accuracy $>85 \%$ dalam uji klasifikasi citra berdasarkan ketetapan USGS (United States Geological Survey) (Sampurno \& Thoriq, 2016). Ditunjukkan pada Tabel 3 hasil uji klasifikasi tutupan lahan.

Tabel 3. Hasil klasifikasi tutupan lahan

\begin{tabular}{|c|c|c|c|c|c|c|c|c|c|c|}
\hline Kelas & 1 & 2 & 3 & 4 & 5 & 6 & 7 & 8 & 9 & Total \\
\hline $\mathbf{1}$ & 27 & 0 & 1 & 0 & 0 & 1 & 0 & 2 & 0 & 31 \\
\hline 2 & 0 & 24 & 0 & 4 & 0 & 0 & 0 & 0 & 0 & 28 \\
\hline 3 & 0 & 1 & 28 & 0 & 0 & 0 & 1 & 0 & 1 & 31 \\
\hline 4 & 0 & 1 & 0 & 25 & 0 & 0 & 0 & 0 & 2 & 28 \\
\hline 5 & 0 & 0 & 0 & 1 & 26 & 0 & 0 & 0 & 0 & 27 \\
\hline 6 & 0 & 0 & 0 & 0 & 0 & 27 & 0 & 0 & 2 & 29 \\
\hline 7 & 0 & 4 & 0 & 0 & 1 & 0 & 29 & 0 & 1 & 35 \\
\hline 8 & 3 & 0 & 0 & 0 & 0 & 0 & 0 & 28 & 0 & 31 \\
\hline 9 & 0 & 0 & 1 & 0 & 3 & 2 & 0 & 0 & 24 & 30 \\
\hline Total & 30 & 30 & 30 & 30 & 30 & 30 & 30 & 30 & 30 & 270 \\
\hline \multicolumn{11}{|c|}{ Overall Accuracy $=88.1481 \%$} \\
\hline \multicolumn{11}{|c|}{ Kappa Coefficient $=0.8667$} \\
\hline \multicolumn{4}{|c|}{ Badan air $=1$} & \multicolumn{3}{|c|}{ Mangrove $=4$} & \multicolumn{4}{|c|}{ Semak Belukar $=7$} \\
\hline \multicolumn{4}{|c|}{ Hutan $=2$} & \multicolumn{3}{|c|}{ Perkebunan $=5$} & \multicolumn{4}{|c|}{ Tambak $=8$} \\
\hline \multicolumn{4}{|c|}{ Lahan Pertanian $=3$} & \multicolumn{3}{|c|}{ Pemukiman $=6$} & \multicolumn{4}{|c|}{ Tanah Kosong $=9$} \\
\hline
\end{tabular}




\section{Peta Bahaya Tsunami}

Bahaya tsunami dihasilan dari Cost Distance menggunakan raster perhitungan rumus Berryman (Hloss) terhadap garis pantai. Dengan menggunakan studi kasus run-up tsunami setinggi 8 meter yang telah terjadi pada tahun 2006 di Kabupaten Pangandaran (BMKG, 2019). Peta indeks bahaya tsunami ini dihitung berdasarkan pengkelasan inundasi sesuai Perka No. 2 BNPB Tahun 2012 (BNPB, 2012). Dari hasil pembuatan peta bahaya tsunami didapatkan hasil daerah terdampak pada Tabel 4.

Tabel 4. Luas area terdampak tsunami

\begin{tabular}{lcccc}
\hline \multirow{2}{*}{ Kecamatan } & \multicolumn{4}{c}{ Luas area terdampak (Hektar) } \\
\cline { 2 - 5 } Cimerak & Kelas Rendah & Kelas Sedang & Kelas Tinggi & Total \\
\hline Cijulang & 86.25 & 116.21 & 161.01 & $\mathbf{3 6 3 . 4 7}$ \\
\hline Parigi & 60.32 & 69.56 & 92.51 & $\mathbf{2 2 2 . 3 9}$ \\
\hline Sidamulih & 41.95 & 86.6 & 208.85 & $\mathbf{3 3 7 . 4}$ \\
\hline Pangandaran & 30.78 & 51.92 & 178.29 & $\mathbf{2 6 0 . 9 9}$ \\
\hline Kalipucang & 72.08 & 104.29 & 225.67 & $\mathbf{4 0 2 . 0 4}$ \\
\hline Jumlah & 48 & 78.36 & 244.87 & $\mathbf{3 7 1 . 2 3}$ \\
\hline
\end{tabular}

Pada Tabel 4 dapat dilihat bahwa luas area terdampak tsunami pada seluruh area studi memiliki luas terdampak tsunami sebesar 1957.52 hektar. Luas area terdampak tersebut terdiri dari 3 kelas bahaya yaitu kelas rendah dengan luas 339.38 hektar, kelas sedang dengan luas area terdampak seluas 506.94 hektar, dan kelas bahaya tinggi seluas 1111.2 hektar. Dengan kecamatan yang paling terdampak yaitu kecamatan Pangandaran dengan luas area terdampak seluas 402.04 hektar. luasan terdampak tersebut terdiri dari 3 indeks bahaya yaitu kelas bahaya tsunami rendah dengan luas area terdampak 72.08 hektar, kelas bahaya sedang terdampak seluas 104.29 hektar, dan kelas bahaya tsunami terdampak seluas 225.67 hektar. Dengan kondisi tutupan lahan di sekitar garis pantai didominasi dengan permukiman, lahan pertanian, dan semak belukar. Kemudian hal tersebut disebabkan oleh kondisi topografi di garis pantai relatif rendah di daerah pesisir Kecamatan Pangandaran dengan kisaran elevasi yang terdampak tsunami yaitu $0-5$ meter di atas permukaan laut.

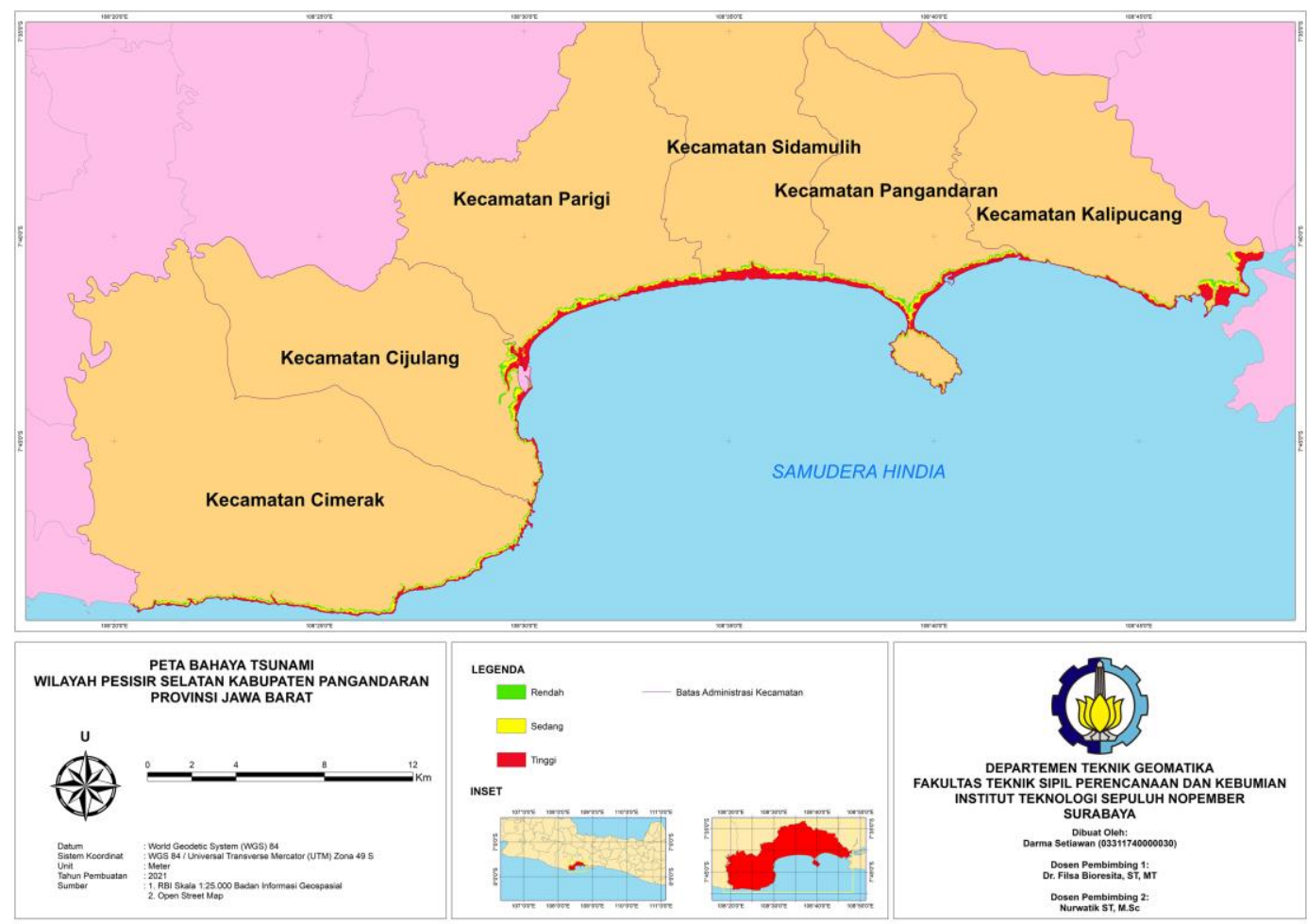

Gambar 1. Peta indeks bahaya tsunami 


\section{Analisa Service Area Lokasi TES}

Titik lokasi TES dilakukan dengan menggunakan data lokasi TES yang sudah ada yang bersumber dari BPBD Kabupaten Pangandaran. Kemudian data tersebut dilakukan analisis service area yang digunakan untuk mengetahui TES tersebut dapat dijangakau oleh masyarakat yang terdampak tsunami. Dimana analisa service area ini merupakan salah satu metode untuk menemukan area layanan di sekitar lokasi TES pada network (jalan) (ESRI, 2019). Berikut adalah hasil service area dari TES yang telah tersedia saat ini yang dimiliki oleh BPBD Kabupaten Pangandaran pada Tabel 5.

Tabel 5. Titik lokasi TES (data BPBD Kabupaten Pangandaran)

\begin{tabular}{|c|c|c|c|c|c|}
\hline \multirow{2}{*}{ Kecamatan } & \multirow{2}{*}{ Desa } & \multirow{2}{*}{ Nama } & \multicolumn{2}{|c|}{ Koordinat } & \multirow{2}{*}{ Keterangan } \\
\hline & & & Lintang & Bujur & \\
\hline Cijulang & Cijulang & TES 1 & $7^{\circ} 43^{\prime} 32.8^{\prime \prime} \mathrm{LS}$ & $108^{\circ} 29^{\prime} 19.3^{\prime \prime} \mathrm{BT}$ & Lahan Kosong \\
\hline \multirow{2}{*}{ Cimerak } & \multirow{2}{*}{ Masawah } & TES 2 & $7^{\circ} 46^{\prime} 52.8^{\prime \prime} \mathrm{LS}$ & $108^{\circ} 29^{\prime} 56.9^{\prime \prime} \mathrm{BT}$ & Lahan Kosong \\
\hline & & TES 3 & $7^{\circ} 47^{\prime} 36^{\prime \prime} \mathrm{LS}$ & $108^{\circ} 28^{\prime} 57.3^{\prime \prime} \mathrm{BT}$ & Lahan Kosong \\
\hline \multirow{2}{*}{ Kalipucang } & \multirow{2}{*}{ Bagolo } & TES 4 & $7^{\circ} 41^{\prime} 19.9$ " LS & $108^{\circ} 45^{\prime} 15.5^{\prime \prime} \mathrm{BT}$ & Lahan Kosong \\
\hline & & TES 5 & $7^{\circ} 41^{\prime} 29.8^{\prime \prime} \mathrm{LS}$ & $108^{\circ} 45^{\prime} 49.4^{\prime \prime} \mathrm{BT}$ & Lahan Kosong \\
\hline Pangandaran & Pangandaran & TES 6 & $7^{\circ} 41^{\prime} 34.5^{\prime \prime} \mathrm{LS}$ & $108^{\circ} 39^{\prime} 13.7^{\prime \prime} \mathrm{BT}$ & Lahan Kosong \\
\hline \multirow{4}{*}{ Parigi } & Ciliang & TES 7 & $7^{\circ} 41^{\prime} 11.4^{\prime \prime} \mathrm{LS}$ & $108^{\circ} 32^{\prime} 12.6^{\prime \prime} \mathrm{BT}$ & Permukiman \\
\hline & Parigi & TES 8 & $7^{\circ} 42^{\prime} 4.9 ” \mathrm{LS}$ & $108^{\circ} 29^{\prime} 40.1^{\prime \prime} \mathrm{BT}$ & Permukiman \\
\hline & \multirow{2}{*}{ Karangjaladri } & TES 9 & $7^{\circ} 42^{\prime} 19.2^{\prime \prime} \mathrm{LS}$ & $108^{\circ} 29^{\prime} 35.5^{\prime \prime} \mathrm{BT}$ & Lahan Kosong \\
\hline & & TES 10 & $7^{\circ} 42^{\prime} 30.5^{\prime \prime} \mathrm{LS}$ & $108^{\circ} 29^{\prime} 56.8^{\prime \prime} \mathrm{BT}$ & Permukiman \\
\hline \multirow{2}{*}{ Sidamulih } & Cikembulan & TES 11 & $7^{\circ} 40^{\prime} 45.6 ” \mathrm{LS}$ & $108^{\circ} 36^{\prime} 46.3^{\prime \prime} \mathrm{BT}$ & Permukiman \\
\hline & Sukaresik & TES 12 & $7^{\circ} 40^{\prime} 42.9^{\prime \prime} \mathrm{LS}$ & $108^{\circ} 35^{\prime} 11^{\prime \prime} \mathrm{BT}$ & Permukiman \\
\hline
\end{tabular}

Analisa service area tersebut dianalisis berdasarkan parameter impedansi waktu tempuh pada setiap akses jalan menuju lokasi TES. Dengan nilai parameter impedansi sebesar 22 menit dihitung dari titik lokasi TES (R. S. Dewi, 2012). Pada data titik lokasi TES yang diperoleh tersebut dari hasil analisa service area, terdapat wilayah yang terdampak tsunami yang tidak terjangkau oleh TES yang telah di tentukan oleh BPBD Kabupaten Pangandaran. Sehingga diperlukannya lokasi TES tambahan untuk menjangkau lokasi yang tidak terjangkau oleh TES yang sudah dibuat tersebut. Gambar 3 menunjukkan hasil service area dari data Tabel 5.

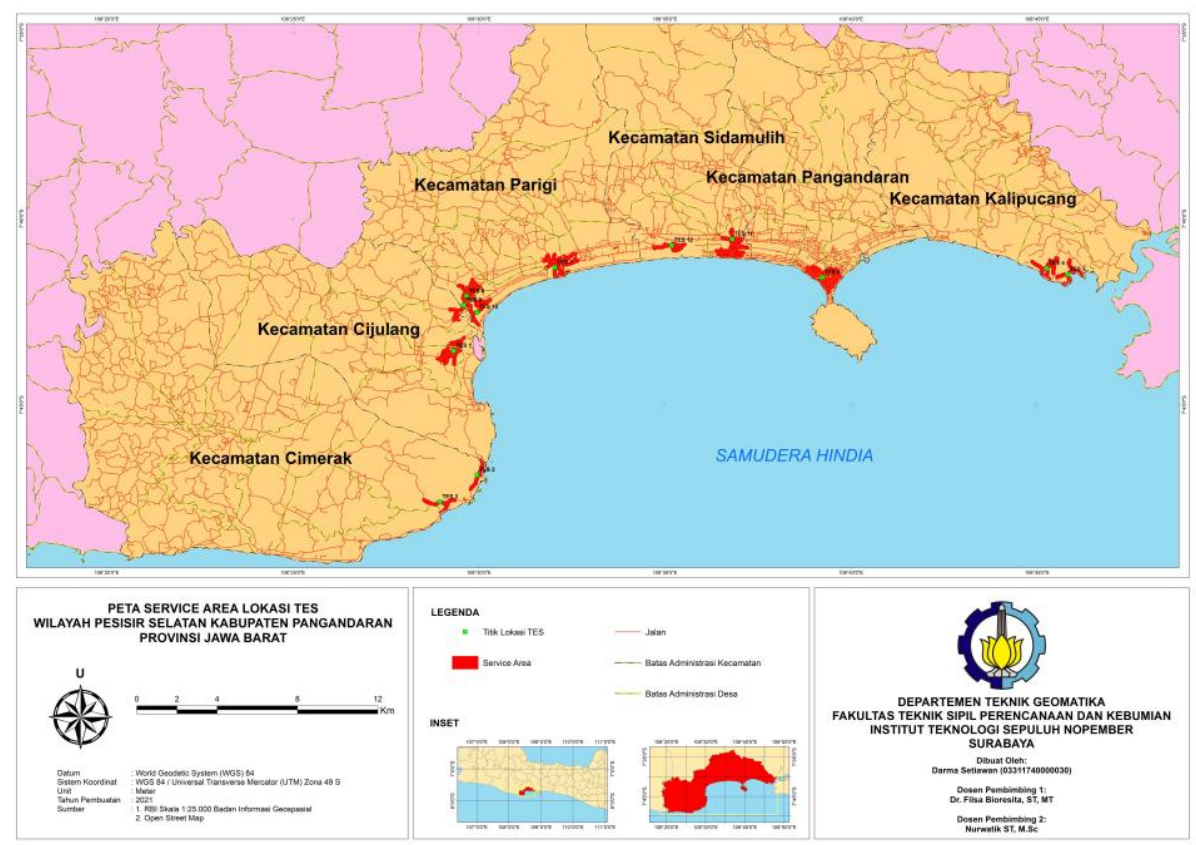

Gambar 2. Peta service area TES data BPBD Kabupaten Pangandaran 
Hasil analisa service area tersebut dilakukan penambahan titik lokasi TES dilokasi yang tidak tercakup oleh hasil service area data BPBD Kabupaten Pangandaran. Untuk menjangkau seluruh area terdampak tsunami dengan TES yang telah dibuat. Setelah dilakukan penambahan lalu dilakukan analisa service area kembali pada data keseluruhan titik lokasi TES untuk memastikan seluruh area telah terjangkau oleh TES yang telah dibuat.

Proses penambahan lokasi TES dilakukan berdasarkan data lokasi TES dari BPBD Kabupaten Pangandaran. Penentuan lokasi TES yang akan ditambahkan dilakukan dengan mempertimbangkan akses jalan dan jenis tutupan lahan yang akan digunakan sebagai lokasi TES. Untuk memaksimalkan TES pemilihan lokasi berada pada lokasi service area TES data dari BPBD kabupaten Pangandaran. Sehingga jumlah lokasi TES tidak terlalu banyak dan membuat bingung masyarakat. Setelah dilakukan penambahan tersebut dilakukan proses analisa service area kembali pada semua titik TES yang telah dibuat untuk memastikan seluruh area bahaya tsunami telah terjangkau oleh area layanan TES berdasarkan analisa network (jalan). Dengan hasil analisa ditunjukkan pada Gambar 3.

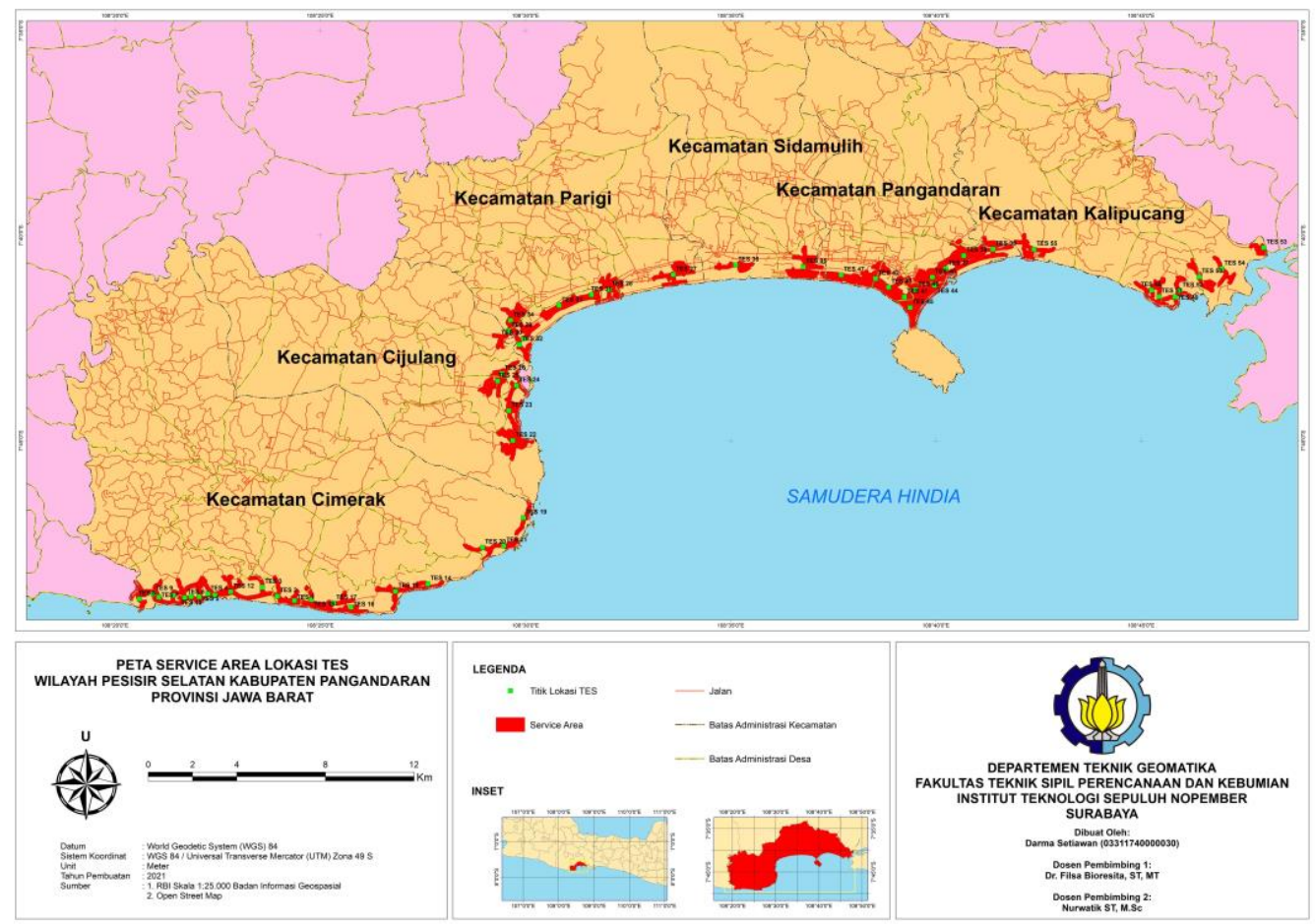

Gambar 3. Peta service area seluruh TES Kabupaten Pangandaran

Dari hasil analisa service area lanjutan tersebut menghasilkan titik lokasi TES sebanyak 43 titik tambahan. Titik tersebut telah menjangkau seluruh network (jalan) yang terdampak tsunami dengan analisa parameter impedansi waktu tempuh selama 22 menit. Sehingga menghasilkan total titik evakuasi sebanyak 55 titik lokasi.

\section{Kesimpulan}

Berdasarkan hasil analisis tingkat bahaya tsunami pada wilayah pesisir selatan Kabupaten Pangandaran didapatkan luas inundasi tsunami seluas 1957.52 hektar. Dengan luas inundasi kelas rendah 339.38 Hektar, kelas sedang 506.94 Hektar, dan kelas tinggi seluas 1111.2 Hektar. Dengan wilayah paling terdampak terletak pada Kecamatan Pangandaran dengan luas area terdampak seluas seluas 402.04 hektar. luasan terdampak tersebut terdiri dari 3 indeks bahaya yaitu kelas bahaya tsunami rendah dengan luas area terdampak 72.08 hektar, kelas bahaya sedang terdampak seluas 104.29 hektar, dan kelas bahaya tsunami terdampak seluas 225.67 hektar. Dari hasil Network Analyst didapatkan jumlah lokasi TES yang diperlukan untuk menjangkau 
seluruh wilayah terdampak tsunami sebanyak 55 titik lokasi TES. Dengan waktu tempuh jalur maksimal selama 22 menit.

\section{Ucapan Terimakasih}

Ucapan terimakasih penulis sampaikan teman-teman Departemen Teknik Geomatika 2017 yang telah membantu dalam penyempurnaan pengerjaan penelitian ini.

\section{Daftar Pustaka}

Berryman, K. R. (2006). Review of Tsunami Hazard and Risk in New Zealand. Igns, September, 139.

BMKG. (2019). Katalog Tsunami Indonesia Tahun 416-2018. BMKG. https://cdn.bmkg.go.id/Web/Katalog-TsunamiIndonesia-pertahun-416-2018.pdf

BNPB. (2012). Master Plan Pengurangan Risiko Bencana Tsunami.

BNPB. (2016). Risiko bencana indonesia. Badan Nasional Penanggulangan Bencana.

Dewi, N. K., \& Purwanto, T. H. (2017). Pemanfaatan OpenStreetMap dan Sistem Informasi Geografis untuk Menyusun Rekomendasi Manajemen Jalan di Sebagian Kota Serang. Jurnal Bumi Indonesia, 6(3), 1-10. http://lib.geo.ugm.ac.id/ojs/index.php/jbi/article/view/762

Dewi, R. S. (2012). A-Gis Based Approach of an Evacuation Model for Tsunami Risk Reduction. Journal of Integrated Disaster Risk Management, 2(2), 108-139. https://doi.org/10.5595/idrim.2012.0023

ESRI. (2019). Types of network analysis layers. ESRI Web. https://desktop.arcgis.com/en/arcmap/10.5/extensions /network-analyst/types-of-network-analyses.htm

Lillesand, T. ., \& Kiefer, R. . (1997). Pengginderaan Jauh dan Interpretasi Citra terjemahan. Gadjah Mada University Press.

Permana, H., \& Rasyid, M. (2007). Pedoman Pembuatan Peta Jalur Evakuasi Bencana Tsunami. Kementrian Riset dan Teknologi RI.

Rai, P. K., Singh, P. K., Singh, A. K., \& Mohan, K. (2013). Network Analysis Using GIS. International Journal of Emerging Technologies in Computational and Applied Sciences ( IJETCAS ), 5(32019), $289-292$.

Sampurno, R. M., \& Thoriq, A. (2016). Klasifikasi Tutupan Lahan Menggunakan Citra Landsat 8 Operational Land Imager (OLI) Di Kabupaten Sumedang. Jurnal Teknotan, 10(2), 61-70.

Tejakusuma, I. G. (2008). Analisis Pasca Bencana Tsunami Ciamis - Cilacap. Jurnal Sains Dan Teknologi Indonesia, $10(2), 78-83$.

Yashinta, V., Nugraha, A. L., \& Firdaus, H. S. (2019). Analisis Kesiapsiagaan Bencana Banjir di Kota Semarang Dengan Menggunakan Data Open Street Map (OSM) dan Inasafe. Jurnal Geodesi Undip, 8(4), 101-112. 